\title{
16. Extending social security to trainees in Spain, France and Germany: A tale of segmentation
}

\author{
Alexandre de le Court
}

\subsection{INTRODUCTION}

A lack of access to social protection and more particularly to social security is one of the problems that have been associated with traineeships or internships in several studies and policy documents. ${ }^{1}$ This problem can also be seen in the context of systemic discrimination against youth (the main participants in traineeships) in the world of work, as argued in Chapter 19 of this volume.

The question of trainees' access to social protection, despite being considered problematic, has not been given much attention in comparative legal studies. Therefore, in this chapter I contribute to the literature on the subject by examining three European Union (EU) member states with social security systems based on professional social insurance (which are situated in the conservative capitalist welfare state cluster or its Mediterranean variation ${ }^{2}$ ) and that have regulated in part the social security rights of trainees. I also briefly look at international and European standards on the matter.

\footnotetext{
1 Andrew Stewart, Rosemary Owens, Anne Hewitt and Irene Nikoloudakis, 'The Regulation of Internships: A Comparative Study' (2018) ILO Employment Policy Department Working Paper No 240; Kari P Hadjivassiliou, Emanuela Carta, Tom Higgins, Catherine Rickard, Suzanne Ter-Minassian, Flavia Pesce and others, Study on a Comprehensive Overview on Traineeship Arrangements in Member States: Final Synthesis Report (European Union 2012); Council Recommendation of 10 March 2014 on a Quality Framework for Traineeships [2014] OJ C88/1; Proposal of the European Commission for a Council Recommendation on access to social protection for workers and the self-employed COM/2018/0132 final. In this chapter I use the words trainee and traineeship, as they are used in the EU regulatory framework.

2 Gøsta Esping-Andersen, The Three Worlds of Welfare Capitalism (Princeton University Press 1990); Maurizio Ferrera, "The "Southern" Model of Welfare in Social Europe' (1996) 1 J Eur Soc Pol 17.
} 
I analyse the extent to which trainees are included within social insurance systems. In doing so I start from the idea that we should consider not only day-to-day work-related risks, such as industrial accidents, but also social risks seemingly less connected with the protection needed by young persons, such as old age. The evolution of the regulation of retirement pensions, requiring longer careers for access to and sufficient level of benefits, combined with a greater irregularity of careers, means young people need to start building up pension rights as soon as possible. Another important branch of social insurance is unemployment protection, given the higher unemployment rates among young people. Social assistance as a safety net will also be briefly included in the analysis.

\subsection{THE SPANISH CASE: TOWARDS COMPREHENSIVE SOCIAL INSURANCE FOR ALL TRAINEES}

One distinctive characteristic of the Spanish case is the existence of a specific fixed-term employment contract for the 'acquisition of professional practice corresponding to the acquired level of studies or training'. The contrato en prácticas (traineeship contract), regulated in section 11 of the Estatuto de los Trabajadores (Act on the Status of Employees), can be concluded for a maximum of two years, within five years of obtaining a degree or professional certificate. While it entails recognition of the full array of labour law and social security rights that apply to an employment contract, it allows the employer to pay lower wages than those of employees performing the same tasks (with a minimum of 60 per cent of the reference wage or statutory minimum wage for the first year, and 75 per cent for the second). It has also been deemed to reinforce the 'chain of precariousness' of fixed-term contracts, ${ }^{3}$ among other reasons because they are excluded from the two-year limit in which a worker can be employed on fixed-term contracts by the same company.

In addition to the traineeship employment contract (and the apprenticeship contract, which is not considered here), non-employment traineeships can be considered an integral part of the Spanish world of work. Their regulation is not unified and the scope of that regulation is not clear, so some doubts arise as to the prohibition of some forms of traineeship and the limits of the employment contract. ${ }^{4}$ A strict reading of the regulation suggests there are three reg-

3 Julia López López, Alexandre de le Court and Sergio Canalda, 'Breaking the Equilibrium between Flexibility and Security: Flexiprecarity as the Spanish Version of the Model' (2014) 5 Eur Lab LJ 18, 37.

4 José Luis Hernández de Luz, 'Becarios y prácticas no laborales en empresas' (2017) 128 Revista del Ministerio de Empleo y Seguridad Social 209, 218-23; 
ulated modalities of traineeship: (1) traineeships for students of professional training programmes (comparable to an apprenticeship); ${ }^{5}$ (2) traineeships for university students; ${ }^{6}$ and (3) traineeships for young unemployed people who possess a degree or training certificate and have less than three months' work experience. $^{7}$

As regards social protection, Act 27/2011 on the update, adaptation and modernization of the social security system, implemented by Royal Decree $1493 / 2011$, requires companies offering paid traineeships to university or professional training students to affiliate the students with the social security system and pay social contributions calculated on the same basis as an apprenticeship contract. Unpaid traineeships do not involve inclusion in the social security system, but paid trainees are covered for all contingencies (retirement and disability pensions, industrial accidents and work-related diseases, sick leave, maternity/paternity leave and health insurance ${ }^{8}$ ), except unemployment.

There was a precedent to this system of inclusion in the social security system. Royal Decree 1326/2003 on the Statute of the Research Trainee (that is, $\mathrm{PhD}$ students or postdoctoral researchers with fellowships) provided that the university or research centre must pay social contributions for those students and protect them against all contingencies, except unemployment. This exception was challenged before the courts, based on an infringement of the equality principle of section 14 of the Spanish Constitution. The Spanish Tribunal Supremo, however, rejected the application, considering that, even if the General Social Security Act authorizes the government to include classes or groups of people who are not employees, civil servants or self-employed in

Mónica Molina García, 'Régimen jurídico de las prácticas no laborales en las empresas' in Margarita Isabel Ramos Quintana and Gloria Pilar Rojas Rivero (eds), Transformaciones del Estado Social y Derecho del Trabajo (Comares 2014) 415; Ana de la Puebla Pinilla, 'Problemas prácticos de la prácticas no laborales en empresas' in Ignacio García-Perrote and Jesús Mercader, Las reformas laborales y de Seguridad Social (Lex Nova 2014) 213, 225-32.

$5 \quad$ Regulated by Royal Decree 1529/2012, art 28ff, developing the apprenticeship contract and establishing the basis of the dual vocational training system.

6 Regulated by Royal Decree 592/2014 on external academic traineeships for university students.

7 Regulated by Royal Decree 1543/2011 on non-employment traineeships in companies. Royal Decree 694/2017 implementing Law 30/2015 on the System of Professional Training for Employment also seems to allow the possibility of regulating traineeships for the unemployed in the framework of active labour market policies (ALMPs) at the level of autonomous communities (the latter are competent to develop ALMPs).

8 The coverage of health insurance is almost universal in Spain, and does not necessarily depend on inclusion in the social security system and the payment of social contributions. 
its scope, the specific provisions on unemployment protection only mention employees and civil servants. Moreover, unemployment benefits are destined to be a substitute for a salary, which the allowance paid to students is not, as it is not paid in consideration of the tasks performed for the university, which are to be considered as secondary to the training of the student, which is the real object of the allowance. Therefore, those students cannot be considered employees. ${ }^{9}$ There is thus no legal or constitutional obligation for the government to provide unemployment protection to people who are not employees or civil servants. This jurisprudence could be considered to make sense if we assume that there is a clear-cut line between research fellowships and employment contracts for research or teaching staff. However, this hypothesis must be questioned. A few years later, Royal Decree 36/2006 on the Statute of the Research Staff in Training (which repealed Royal Decree 1326/2003) provided that the two first years of collaboration of PhD students with their institution would take the form of a trainee fellowship, while further years of collaboration would have to take the form of a fixed-term employment contract, despite there being no difference in the students' tasks. Moreover, Act 14/2011 on Science, Technology and Innovation provided that the collaboration of $\mathrm{PhD}$ students with their institution had to take the form of an employment contract from the start, abolishing de facto the possibility of traineeships linked to pre-doctoral or postdoctoral training.

Since 2011, paid traineeships (independently of their specific regulation) have involved inclusion in the social security system, with the provider of the training paying social contributions. Unpaid traineeships have not. ${ }^{10}$

However, the latter situation is supposed to change. The fifth additional provision of Legislative Royal Decree 28/2018 on the increase of public pensions and other urgent measures in social, work and employment matters ${ }^{11}$ provides that all trainees are to be included in the social security system (except for protection in case of unemployment), whether their traineeships are paid or unpaid. That provision is not yet in force. This would depend on the adoption of a royal decree for its implementation within three months of the publication of the legislative decree. However, negotiations with universities seem to have

9 Tribunal Supremo, sala de lo contencioso-administrativo, judgment of 28 June 2005 (case 150/2003).

10 Except for health care, owing to its quasi-universal character.

11 The lack of social protection for unpaid trainees is presented in the preamble of the law as one of the justifications of the urgency permitting the government to adopt legislative measures normally reserved for Parliament. 
postponed the entry into force of the measure, so that in August 2020, the Royal Decree had not yet been adopted. ${ }^{12}$

The Spanish case is thus an example of a process of cumulative change in the formalization of traineeships as a contractual relationship involving inclusion in the social security system, next to the more traditional categories of workers, such as employees, civil servants and the self-employed. The government is gradually assimilating trainees into the category of employees, applying a general power of assimilation provided by social security law. Inclusion in social security extends to long-term protection (including for old age) and recognition of the existence of traineeships as part of the employment trajectory. Protection does not extend to security for people in transition between jobs, with the consolidated and reiterated exclusion of unemployment protection. In this the Spanish government seems to hide behind the pretext of a strict and formal interpretation of the law and the Constitution to avoid the financial burden of extending unemployment insurance. However, this exclusion is problematic when viewed within the context of a youth unemployment rate of 33.2 per cent in 2019 according to Eurostat. Also, since the young unemployed are generally excluded from social assistance benefit schemes (which, in Spain, are fragmented and different in each autonomous community), ${ }^{13}$ there is a higher risk that there will be no safety net in times of unemployment after a career start in which traineeships have played an important part.

12 See Conferencia de Rectores de las Universidades Españolas (Conference of Spanish Public University Presidents), 'Crue lamenta que al Gobierno legisle en al RDL 28/2018 sobre las prácticas académicas externas sin hablar con las universidades y reclama diálogo urgente para abordar conjuntamente esta cuestión' (Crue, 4 January 2019), https://www.crue.org/2019/01/comunicado-practicas-academicas-externas/, accessed 30 March 2021; 'Crue Universidades Españolas agradece la decisión del Gobierno de abrir un diálogo sobre las prácticas académicas externas' (Crue, 16 January 2019), https://www.crue.org/2019/01/crue-agradece-dialogo-practicas-acad emicas-externas/, accessed 30 March 2021. The practice of integrating obligatory traineeships into university degrees is widespread (540 000 students according to the Spanish Ministry of Work), and it is believed that an obligation to pay a social contribution would deter companies from accepting trainees. Moreover, part of those traineeships involves collaboration with the academic or training institutions themselves, and the law provides for the possibility of the institution paying the contributions even for traineeships in companies not linked to the institution.

13 The minimum age requirement is 25 in Madrid or 23 in Catalonia, the Basque Country and in relation to the recently approved nationwide Ingreso Minimo Vital (with some exceptions). 


\subsection{THE FRENCH CASE: THE LEVEL OF THE ALLOWANCE AS A CRITERION OF INCLUSION}

Act 2014-788 of 10 July 2014 for the development and regulation of traineeships (stage) and the improvement of the status of trainees, reforming the Education Code, was the culmination of a series of measures taken since 2006 to bring the status of trainees closer to that of employees in relation to social rights. ${ }^{14}$ The model rests on the strict regulation of traineeships. Traineeships can only occur within the framework of a tripartite training relationship between a company or entity, an educational institution and the student. Open-market traineeships are forbidden, ${ }^{15}$ and emphasis is put on the training component of the relationship. ${ }^{16}$ The regulation makes it clear that traineeships cannot be used to crowd out formal employment: the code explicitly prohibits the use of trainees for regular tasks corresponding to permanent work, to cover a temporary increase in activity, to perform seasonal work or to substitute for another worker who is on leave. ${ }^{17}$ Traineeships of more than two months involve the obligatory payment of a minimum allowance established in the applicable branch-level agreement, or if not by governmental decree, of at least 15 per cent of the plafond horaire de la sécurité sociale, a reference amount used for the calculation of particular social benefits. For 2019, the minimum allowance is established at $€ 3.75$ per hour, or $€ 577$ per month for a full-time traineeship.

Trainees remain affiliated to the social security system under their student status. They are included in the social security coverage for industrial accidents or work-related diseases (with contributions paid by their education institution). ${ }^{18}$ However, if the allowance exceeds the minimum allowance fixed by the Education Code, inclusion in social insurance is compulsory and the employer's social contributions are paid by the company hosting the

14 Christophe Willmann, 'L'assurance vieillesse, face aux difficultés professionnelles des jeunes' (2014) 6/7 Droit Social 617, 621.

15 The Code du Travail also provides for traineeships in the framework of long-life training or ALMPs, but they generally involve the payment of a salary or allowance, inclusion within the social security system, and consideration of the traineeship period for the accumulation of retirement pension rights (Code du Travail, art L6342-1 ff; Code de la Sécurité Sociale, art L-351-3).

${ }_{16}$ Code de l'Education, art L124-1 also refers to 'placing the trainee in a work situation' (mise en situation).

17 Ibid art L124-7.

18 Code de la Sécurité Sociale, arts L412-8, R412-4. 
traineeship. ${ }^{19}$ The traineeship period will be taken into account for access to maternity/paternity leave and sick leave as well as disability pension. ${ }^{20}$

The traineeship period can also contribute to access to the retirement pension. ${ }^{21}$ If the trainee receives an allowance above the minimum, contributions are paid for the difference between the allowance and that minimum. These contributions are taken into account in the future assessment of the retirement pension. ${ }^{22}$ Moreover, if there is no allowance or if the latter is lower than or equal to the minimum, it is possible to 'validate' the traineeship period to build pension rights up to a specific limit (two fictive trimesters) if the student pays a set contribution, up to two years after the end of the traineeship. ${ }^{23}$ However, few trainees are able to exercise that option, and the general level of the allowances is too low to involve a generalized contribution of traineeships towards pension rights. ${ }^{24}$

Even when social contributions are paid (that is, the allowance is above the legal minimum) traineeship periods are not taken into account for the right to unemployment benefits, because the trainee is not considered an employee, and only contributions paid on the basis of the salary of an employee are taken into account. The remuneration received by the trainee is explicitly defined as an allowance, or gratification, so it does not qualify as a salary.

Concerning general social assistance benefits, the means-tested and means-complementing Revenu de Solidarité Active is conditional on reaching the age of 25. There are two exceptions to this: having responsibility for children $^{25}$ or having worked a specific number of hours (twice the annual threshold from which working hours are considered extra working time, the

\footnotetext{
Ibid art R412-4.

Ibid art L136-1-1(III)(b).

Willmann (n 14) 620.
}

22 Fictive trimesters of work are recognized according to thresholds calculated on the basis of a number of hours multiplied by the hourly minimum salary (around $€ 1500$ per trimester in 2019). Therefore, reaching the necessary thresholds depends on the combination of hours worked under the traineeship contract and the difference between the minimum allowance and the allowance effectively received.

23 See Code de la Sécurité Sociale, art L351-17.

24 In 2010 around 30 per cent of trainees received an allowance above the minimum (64 000 students), but only 4 per cent were able to 'validate' a trimester, with an allowance superior to $€ 1008$ per month: Yannick Moreau, Rapport au Premier minister: Nos retraites demain: équilibre financier et justice (Direction de l'information légale et administrative 2013) 121. For the academic year 2016-17, 54 per cent of traineeships lasted two months or more, 46 per cent involved an allowance, but only 28 per cent of the allowances were more than $€ 600$ per month: Ministère de l'Enseignement supérieur, de la recherche et de l'innovation, 'Un tiers des étudiants en université ou établissement assimilé a suivi un stage en 2016-2017' (2018) Note Flash No 14.

25 Code de l'Action Sociale, art L262-4. 
latter being 1607 hours) in the three years previous to the request for assistance. ${ }^{26}$ However, hours worked under a traineeship contract are not taken into account. Also, the French youth guarantee system gives young people between 16 and 25 years of age without sufficient resources access to a benefit which can be combined with a traineeship allowance as long as their income is below a certain threshold. ${ }^{27}$

\subsection{THE GERMAN CASE: A COMPLEX SYSTEM BASED ON THE LINK WITH EDUCATION}

The Mindestlohngesetz (Minimum Wage Act) is the main piece of legislation which explicitly defines the legal concept of trainee (Praktikant/in). According to its section 22, a trainee is a person who, according to the contractual relationship and its execution, undergoes a specific period of activity in preparation for a profession, to acquire practical knowledge and experience. The definition recognizes the right to the minimum wage, with some exceptions: (1) compulsory traineeships (Pflichtpraktikum), which are covered by regulations on training, education and higher education; (2) voluntary orientating traineeships (before vocational training or studies) of less than three months; (3) voluntary traineeships of less than three months during a course of study (that is, when the trainee is enrolled as a student); and (4) traineeships in the context of active labour market policies (ALMPs).

The Minimum Wage Act reflects the differentiation, in terms of regulation, between compulsory (Pflichtpraktikum) and voluntary traineeships (Freiwilliges Praktikum). In the former, the legal status of enrolled student stands at the heart of the activity, and the relevant rights and obligations are laid down in school regulations and study and examination regulations of colleges and universities, ${ }^{28}$ which have a public law character and govern the administrative relationship with the place where the traineeship takes place. ${ }^{29}$ Voluntary traineeships, on the other hand, have a private law character, and fall under the scope of the Berufsbildungsgesetz, or Vocational Training Act,

\footnotetext{
26 Ibid arts L262-7-1, D262-25-1 ff.

27 Code du Travail, arts L5131-6 ff, R-5131-16 ff.

28 Tobias Wolfgarten and Markus Linten, 'National Report on Traineeships in Germany' in Kari P Hadjivassiliou, Emanuela Carta, Tom Higgins, Catherine Rickard, Suzanne Ter-Minassian, Flavia Pesce and others, Study on a Comprehensive Overview on Traineeship Arrangements in Member States: Final Synthesis Report (European Union 2012) 232.

29 Julia Burkard-Pötter and Stephan Sura, 'Das Praktikum im neuen Gewand Praxiseinblicke zwischen Mindestlohn und prekärem Beschäftigungsverhältnis’ (2015) Neue Juristische Wochenschrift 517, 518-19.
} 
section 26. Some of its provisions apply to the traineeships it defines (the obligations of the parties related to the object of the contract, the conditions for termination, and the application of labour law provisions in accordance with the characteristics and purpose of the traineeship/vocational training contract). On the one hand, the Vocational Training Act differentiates the traineeships to which it applies from the employment relationship and the vocational training relationship..$^{30}$ On the other, it defines the 'private law' or voluntary trainee as a person who has been hired to acquire professional knowledge, skills, capacities or experience.

Another difference between voluntary and compulsory traineeships is that, in the former, trainees are not considered persons 'hired for their vocational training', which is a legal category used to regulate compulsory inclusion in the social security system. ${ }^{31}$ In the latter instances, trainees are considered to be such persons, through the inclusion of compulsory traineeships in the definition of vocational training by the Vocational Training Act (even if they do not fall under the scope of section 26 and are excluded from the extension of labour law provisions). ${ }^{32}$ The rules of social insurance are thus different for each category.

Social security rights vary according to three main factors: the voluntary or compulsory character of the traineeship, whether it occurs during a course of study or before or after (thus distinguishing between Zwischenpraktikum and Vor- or Nachpraktikum; the former takes place while the trainee is enrolled as a student, while the latter is imposed by training or study regulations before enrolment or after obtaining the degree or diploma), and whether the trainee receives pay or not. The fragmented character of German social insurance, with different regimes for different social risks to be covered, adds to the complexity of the question. ${ }^{33}$ However, the situation can be summarized as follows.

In principle, an obligatory traineeship, paid or unpaid, must be covered by pension insurance, ${ }^{34}$ except if it takes place during the course of study (the

30 As explained in Chapter 7 in this volume, vocational training is intended to impart workplace competencies in an orderly course of training, with vocational school lessons and examinations. The difference from the employment contract resides mainly in that the training and learning is in the foreground. See also Wolfgarten and Linten (n 28).

31 See Sozialgesetzbuch IV (hereafter, $S G B I V$ ) on General Provisions on Social Insurance, s 2(2), for the general principle of inclusion.

32 Berufsbildungsgesetz, s 3(2).

33 Pflegeversicherung, or nursing care insurance, is not considered here, and follows roughly the lines of health insurance, to which it is connected.

$34 \quad S G B V I, \mathrm{~s} 1$ (pension insurance). 
exception also stands if that Zwischenpraktikum is paid). ${ }^{35}$ The latter type of traineeship is also exempted from compulsory inclusion in unemployment insurance (even if paid), ${ }^{36}$ while a traineeship before or after a course of study must be included. ${ }^{37}$

All compulsory traineeships must include health insurance, whether they are paid ${ }^{38}$ or unpaid. ${ }^{39}$ However, some benefits, such as sickness benefits, are only available to paid trainees (again with an exclusion for compulsory traineeships during a course of study).$^{40}$ Also, all trainees are covered in case of industrial accidents, whether as 'hired persons' (paid or unpaid) or as students following higher education. ${ }^{41}$

In compulsory Vor- or Nachpraktikum, contributions are calculated in the same way as for employees. However, if the allowance is less than $€ 325$ per month, which includes unpaid traineeships, only the employer has to pay contributions. The latter have to be at least 1 per cent of the Bezugsgröße, a legally defined reference amount for the calculation of social benefits. ${ }^{42}$ This rule applies to pension and unemployment insurance. For health insurance, the principle of payment by the employer in relation to unpaid traineeships is overridden by the application of the health insurance coverage of the family, and another fictive amount is taken into consideration for the calculation of contributions.

As explained previously, voluntary traineeships do not involve inclusion in the social security system of the trainee as a 'person hired for his or her vocational training'. Therefore, the other general ground of inclusion in the social security system, that is, 'being hired for remuneration', applies. ${ }^{43}$ As a consequence, as there is no explicit rule providing for their inclusion, unpaid voluntary trainees are not compulsorily insured. Therefore, they are not included in pension, health care and unemployment insurance. However, they are included in industrial accident insurance, as receiving remuneration is not a necessary

35 Ibid s 5(3) (pension insurance). This type of traineeship does not give the right to the minimum wage either (it is one of the exceptions in Mindestlohngesetz, s 22).

$36 S G B I I I$, s 27(4) (unemployment insurance). The latter exemption applies to all working students during their studies.

37 Ibid s 25 (unemployment insurance).

$38 S G B V, \mathrm{~s} 5(1) 1$ (health insurance). In this case they are included as persons 'hired for their vocational training who receive a remuneration', assimilated to employees.

39 Ibid s 5(1)10. In this case they are included as persons 'hired for their vocational training without receiving a remuneration'.

40 Ibid s 44 (1).

$41 \quad S G B V I I, \mathrm{~s} 2(1) 8$.

$42 \quad S G B V I, \mathrm{~s} 162(1)$.

$43 \quad S G B I V, \mathrm{~s} 2(2) 1$. 
condition. ${ }^{44}$ In this context, it is also important to remember that voluntary traineeships of more than three months before or during a course of study, as well as voluntary traineeships after study, are entitled to the minimum wage. Also, their inclusion in the scope of part of the provisions of the Vocational Training Act gives trainees the right to 'adequate compensation', ${ }^{45}$ which is also subject to social contributions. ${ }^{46}$

Paid voluntary trainees are thus treated like any other employee for social security purposes. However, in line with the system of 'mini-jobs', if the remuneration is less than $€ 450$ per month (owing to, for example, low 'adequate compensation' or a part-time traineeship remunerated at the minimum wage), there is no compulsory inclusion in social insurance, ${ }^{47}$ except for industrial accidents.

Finally, there is a difference between the treatment of young people and the rest of the population in relation to social assistance. Social assistance benefits for people who are able to work (Arbeitslosengeld II, also known as Hartz $I V$ benefits) and who are under 25 years of age are overtaken by help from their family (therefore, the person needs an authorization from the controlling administration - the job centre - to leave the family home, which is only given in exceptional circumstances) and sanctions in case of non-compliance with obligations related to rapid labour market integration are heavier.

Table 16.1 provides an approximate summary of the situation. It shows that for voluntary traineeships (that is, traineeships that are not required under education or training regulations) pay is a determining factor (notwithstanding the extension of the mini-job regulations to traineeships) in the extension of social insurance to trainees. However, for compulsory traineeships, it is when they take place, and thus their connection with the formal education or training period, that determines the applicable law. During this period, the trainee also has the status of a student. Moreover, it seems that the lack of the right to the minimum wage for compulsory traineeships (which could reflect the need to make them widely available, so that all students can fulfil the conditions of their course of study) is compensated by obligatory insurance and payment of contributions by the employer. Finally, the extended right to minimum pay for voluntary trainees, apart from the mini-jobs system, involves compulsory inclusion in social insurance, and the application of some labour law provisions through the Vocational Training Act. This indicates a strong convergence with

\footnotetext{
$44 \quad S G B$ VII, s 2 abs 1 no 1.

45 Berufsbildungsgesetz, s 17.

46 Dirk Schnelle, Die Berufsbildung der Volontäre und Praktikanten (Peter Lang 2010) 32 .

$47 S G B V I$, s 5(2) for pension insurance; $S G B V$, s 7 for health insurance; $S G B I I I, \mathrm{~s}$ 27(2) for unemployment insurance.
} 
Table 16.1 Summary of social insurance for trainees in Germany

\begin{tabular}{lll}
\hline $\begin{array}{l}\text { Compulsory traineeship (does not include } \\
\text { the right to the minimum wage) }\end{array}$ & $\begin{array}{l}\text { Before or after } \\
\text { studies }\end{array}$ & $\begin{array}{l}\text { Compulsory insurance (some } \\
\text { benefits not accessible if unpaid) }\end{array}$ \\
\cline { 2 - 3 } & During studies & No compulsory insurance \\
\hline Voluntary traineeship (includes the right to & Paid and above & Compulsory insurance \\
the minimum wage, with exceptions) & $€ 450$ per month & \\
\cline { 2 - 3 } & Unpaid or under & No compulsory insurance \\
& $€ 450$ per month & \\
\hline
\end{tabular}

the status of employee, even if there are remaining differences in the level of salary and labour rights. This, together with the difficulty of separating traineeships from employment based on the legal definitions, will not solve the significant problem of disguised employment. ${ }^{48}$

Finally, the segmentation between trainees, while depending on legal technicalities related to the definitions of vocational training or the public or private character of the different traineeship relations, could be systematized by thinking of the link to formal education as a guarantee of the effectiveness of the training tasks (or materially reinforcing that content, and the student status of the trainee). Social protection (including labour law protection) could thus be seen as being inversely proportional to the guarantee of the quality of the training or the importance of the traineeship for the acquisition of the desired capacities.

\subsection{THE LACK OF INTERNATIONAL AND EFFECTIVE EU STANDARDS ON SOCIAL PROTECTION FOR TRAINEES}

Against the backdrop of a lack of specific international standards for trainees, the restriction of the application of most International Labour Office (ILO) conventions on social security to employees ${ }^{49}$ means that the ILO instruments have little relevance in that matter.

However, at the level of the EU, attention has been given to traineeships in the framework of employment policy. For example, traineeships seem to be the second most used measure proposed by the Youth Guarantee, after employment. ${ }^{50}$ However, the Youth Guarantee does not regulate the traineeships to be provided.

\footnotetext{
48 Burkard-Pötter and Sura (n 29).

49 Stewart and others (n 1) 81.

50 European Commission, Traineeships under the Youth Guarantee: Experience from the Ground (European Commission 2018) 6.
} 
That issue is the object of the Council Recommendation of 10 March 2014 on a Quality Framework for Traineeships. While its recital 9 recognizes that the lack of social security coverage is one of the problems that have been identified, its point 7 only recommends that member states 'encourage traineeship providers to clarify whether they provide coverage in terms of health and accident insurance as well as sick leave'. Moreover, according to recital 28, the recommendation does not apply to 'work experience placements that are part of curricula of formal education or vocational education and training' or 'traineeships the content of which is regulated under national law and whose completion is a mandatory requirement to access a specific profession'.

Another EU document that might be of interest in the context of this study is the Recommendation of the Council of the European Union of 8 November 2019 on access to social protection for workers and the self-employed. ${ }^{51}$ Here, the recitals mention trainees among the categories of workers which in some member states are excluded from social protection schemes. ${ }^{52}$ However, while the recommendation aims 'to provide access to adequate social protection to all workers and the self-employed in member states', it seems that not all trainees would be included in its scope. The Court of Justice of the European Union (CJEU) does recognize that trainees can be considered as workers under EU law. ${ }^{53}$ It seems, however, from that notion that remuneration is a determining element. This view also seems to be confirmed by the definition of worker in the proposal itself, which runs along the lines of the jurisprudence of the CJEU. The scope of application would thus be limited to paid traineeships. This is to be regretted, as its principles, if applied effectively (which is not guaranteed, given the soft law character of the document) would inevitably enhance the social protection of the trainees in its scope. It does not only ask that mandatory coverage be extended (including pension rights and unemployment benefits, which are not envisaged in the Quality Framework), but also that the obstacles to trainees accessing benefits be considered, and that

51 Recommendation of the Council of the European Union of 8 November 2019 [2019] C387/1.

52 See eg recital 18.

53 CJEU, Judgment of 30 March 2006, Case C-10/05 Mattern, para 18, where the applicant completed a professional training period as a care assistant. See also Martin Risak and Thomas Dullinger, The Concept of 'Worker' in EU Law: Status Quo and Potential for Change (ETUI 2018) 34-5; Conclusions of Advocate General Alber in Case C-92/02. In that case, in its judgment of 4 December 2003, the CJEU held that the right to free movement of a postdoctoral assistant receiving a fellowship (considered a worker under EU law) does not imply that these 'trainees' should have the right to social insurance in the member state of residence, as long as they are treated equally with the nationals of that member state. 
any difference in treatment should be proportionate and reflect the particular situation of the trainees.

The EU framework might thus be seen as fragmented and contradictory, in that it promotes the use of traineeships and at the same time recognizes the deficits in social protection without genuinely reinforcing guarantees of protection.

\subsection{THE PROBLEMATIC LOGIC BEHIND SEGMENTATION}

The case studies in this chapter suggest a positive trend of extending social security rights to trainees in the light of the general problem of the lack of social protection highlighted in the literature on the subject. However, in all cases, segmentation is an important feature of the regime of protection.

While there is a certain convergence with the protection awarded to employees, trainees do not enjoy the same rights. In an attempt to systematize possible rationales behind the differences, without endorsing the logic of the segmentation, two main elements can be observed. The first is the link, formal or material, with training. In France and in Germany, it is when there is a link with formal education (for all traineeships in France, and for compulsory traineeships in Germany) that trainees are the furthest from enjoying the same rights as employees. In Spain, where there is also a traineeship employment contract, it is the prominent objective of the contract (and the corresponding consideration of the allowance as material help to facilitate the acquisition of skills) which determines the different social security rights. Also, that an allowance is not being classified as a salary is another ground of segmentation, as well as an excuse for jurisprudence to refuse to apply equal treatment frameworks. In light of this, the proposed EU recommendation on workers' access to social protection might prove insufficient to guarantee the extension of that protection.

There is also segmentation between different categories of trainees. Here, the level of the allowance seems to be the determining factor (together with the link with formal education in Germany expressed by the exclusion of compulsory traineeships during a course of study). It is thus the perception of the value of the trainee by the employer which indirectly triggers the protection. Moreover, this would be an incentive for employers not to pay high allowances. From that perspective, the extension of minimum wage rights, as in the German case (although tempered by exceptions and the mini-jobs exemptions), acquires a particular significance, which also shows the general importance of analysing social security rights in connection with labour law.

Finally, the widespread exclusion from unemployment protection of trainees and the difficulties for young adults of accessing social assistance in the 
three cases shows that the idea of youth as 'undeserving' of social protection still strongly inspires regulation, ${ }^{54}$ and reinforces the systemic discrimination against them.

54 For a critique of that idea, in the context of the French Revenu de solidarité active, see Juliana Bidadanure, 'Short-Sightedness in Youth Welfare Provision: The Case of RSA in France' (2012) 1 Intergenerational Just Rev 22. 